\title{
Isolation and Identification of LABs through Morphological and Biochemical Characteristics from Curd Sample
}

\author{
A. Krishnaveni ${ }^{1}$, B. Murugan ${ }^{2 *}$, T. R. Pugazhenthi ${ }^{3}$, \\ I. Manikkavasagan ${ }^{2}$ and R. P. Aravindh Babu ${ }^{4}$
}

${ }^{1}$ Department of Food Technology, ${ }^{2}$ Department of Food Safety and Quality Assurance, College of Food and Dairy Technology, Tamil Nadu Veterinary and Animal Sciences University, Chennai, India

${ }^{3}$ Department of Livestock Products Technology (Dairy Science), Madras Veterinary College, Tamil Nadu Veterinary and Animal Sciences University, Chennai, India

${ }^{4}$ TRPVB, Tamil Nadu Veterinary and Animal Sciences University, Madhavaram, Milk colony, Chennai, India

*Corresponding author

\section{A B S T R A C T}

\begin{tabular}{l} 
K e y w o r d s \\
$\begin{array}{l}\text { Lactic acid bacteria, } \\
\text { Curd, Isolation, } \\
\text { Identification }\end{array}$ \\
Article Info \\
\hline $\begin{array}{l}\text { Accepted: } \\
18 \text { August } 2020 \\
\text { Available Online: } \\
\text { 10 September } 2020\end{array}$ \\
\hline
\end{tabular}

\section{Ke y w o r d s}

Lactic acid bacteria, Curd, Isolation, Article Info

\section{Introduction}

Curd is one of the Indian traditional fermented dairy products which is used as a main food sources in daily life. The curd contains viable lactic acid bacteria (LAB) which includes probiotic bacteria and their metabolic by-products that possess certain antioxidant, immune modulator and antimicrobial activities.
A total of 62 strains of lactic acid bacteria (LAB) were isolated from 18 curd samples (i.e. household curd) collected from seven agro-climatic zones of Tamilnadu. MRS and M17 agar and broth medium were used in this study for isolating individual colonies and propagation in broth culture. The 62 isolated strains were identified on the basis of their morphological, cultural and biochemical characteristics. Horrel-Elliker test was used to identify the isolates having better starter activity and accordingly isolate numbers DS 6, 9, 12,18 and 39 which produced maximum acidity $0.261 \pm 0.002,0.262 \pm 0.002,0.255 \pm$ $0.001,0.263 \pm 0.001$ and $0.255 \pm 0.001$ of lactic acid respectively. All isolates were homofermentative and 24 isolates were identified as Lactobacillus, 12 isolates as Streptococcus, 19 isolates as Leuconostoc and 7 isolates as Enterococcus species at genus level. 
during their development (Kumar and Kumar, 2014).

Lactic acid bacteria are a group of gram positive, non-sporulating, aerobic or facultative anaerobic, cocci or rods that produce lactic acid as one of the major fermentation products for carbohydrates metabolism. These naturally occurring bacteria are non-pathogenic to human and animals and are considered as Generally Recognized as Safe (GRAS) organisms (Chowdhury and Saiful, 2016).

Lactic acid bacteria are grouped into categories of homofermenter or heterofermenter based on the final product of fermentation. Homoferm enter produces lactic acid as the main product of glucose fermentation, while heterofermenter produces lactic acid, carbon dioxide, acetic acid and ethanol from glucose fermentation. $\mathrm{LAB}$ is recognized for its ability to ferment and thus improve food safety, improve organoleptic characteristics, enrich nutrients and increase health benefits (Wassie and Wassie, 2016). The objective of this study was to isolate, identify and characterize field isolates of lactic acid bacteria from the home-made curd sample.

\section{Materials and Methods}

\section{Collection of samples}

A total of eighteen curd samples i.e. household curd were collected from seven Agro climatic Zones of Tamil Nadu. The collection of curd samples was done in sterile, autoclavable sample bottles. After collection, the samples were transported to the laboratory in an ice box and stored at $4^{\circ} \mathrm{C}$ for further use.

\section{Isolation of Lactic Acid Bacteria (LAB)}

Curd samples collected from different places were subjected up to $10^{-7}$ serial dilution, plated on sterile De Man, Rogosa and Sharpe (MRS agar) / M17 agar petri plates and kept at $37^{\circ} \mathrm{C}$ for 24 hours. After incubation, 150 colonies were picked randomly and inoculated in MRS/M17 broth for identification. The inoculated samples were kept at $37^{\circ} \mathrm{C}$ for 24 hours and they were stored at $4^{\circ} \mathrm{C}$ for further study after proper growth.

\section{Identification of Lactic acid bacteria using the conventional method}

MRS /M17 broth were used for overnight cultures of each isolate for the identification of lactic acid bacteria. A loop full of each isolate was inoculated into $10 \mathrm{ml}$ of $3 \%$ sterilized reconstituted milk and those coagulating the milk sample were taken for further studies. A total 62 isolates were selected from 150 isolates and examined for identification of Lactic acid bacteria.

All bacterial isolates were initially tested for cell morphology, motility, gram reaction, catalase production, growth at different temperature $\left(10^{\circ} \mathrm{C}, 40^{\circ}\right.$ and $\left.45^{\circ} \mathrm{C}\right)$, growth at different $\mathrm{NaCl}$ concentration $(2 \%, 4.5 \%$ and $6.5 \%$ ) and fermentation of carbohydrates(viz.) galactose, glucose, lactose, maltose, mannitol, sorbitol, sucrose, raffinose and xylose, according to the methods described by (Kebede., 2007).Identification of LAB was done based on morphology and biochemical characteristic (Yadav et al.,1993).

Isolated Lactic acid bacteria were tested for the activity of starter culture by Horrel Elliker's method. $0.3 \mathrm{ml}$ of culture was inoculated in $10 \mathrm{ml}$ of $3 \%$ sterilized reconstituted milk and incubated at $37^{\circ} \mathrm{C}$ for 3 $1 / 2$ hours. After incubation it was titrated against $0.1 \mathrm{~N} \mathrm{NaOH}$ with phenolphthalein as an indicator. The end point was the appearance of pale pink colour. 
The isolated lactic acid bacteria were further subjected to creatine test, $2.5 \mathrm{ml}$ of culture, 1 $2 \mathrm{mg}$ of creatineand $2.5 \mathrm{ml}$ of sodium hydroxide was taken in a test tube. The mixture was shaken thoroughly and allowed to stand for 10 minutes. The formation of pink colour was observed as the positive reaction.

All LAB strains were characterized and identified to the genus level according to Bergey's Manual of Determinative Bacteriology (Yadav et al., 1993).All 62 isolates were stored in $15 \%$ glycerol containing MRS broth and held at $-20^{\circ} \mathrm{C}$ for further study.

\section{Results and Discussion}

A total of 150 isolates were collected from 18 home-made curd samples that was taken from seven agro-climatic zones of Tamilnadu, of which 62 isolates were properly coagulated by milk samples and they were taken for further studies.

In this study spread plate method was used. Different species of LAB colonies are shown in Figure 1 and 2.The results of microscopic examination are shown in the Figure 3 and 4 and the cultural, morphology and biochemical characteristics of LAB are presented in Table 1.

Fig.1 LAB colonies in MRS agar

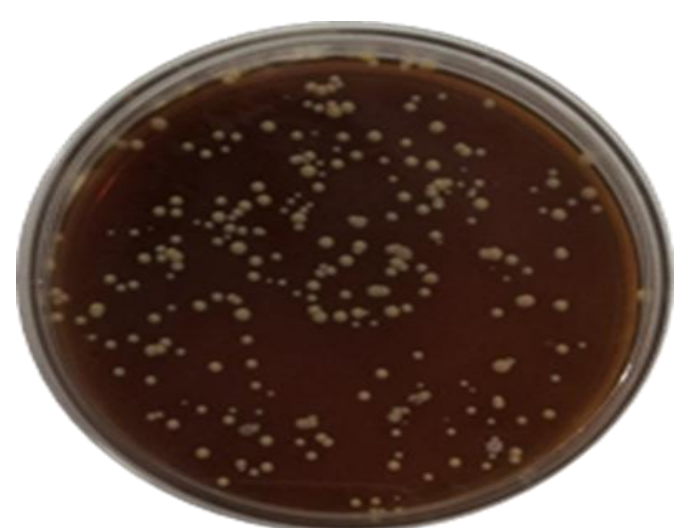

Fig.2 LAB colonies in M17 agar

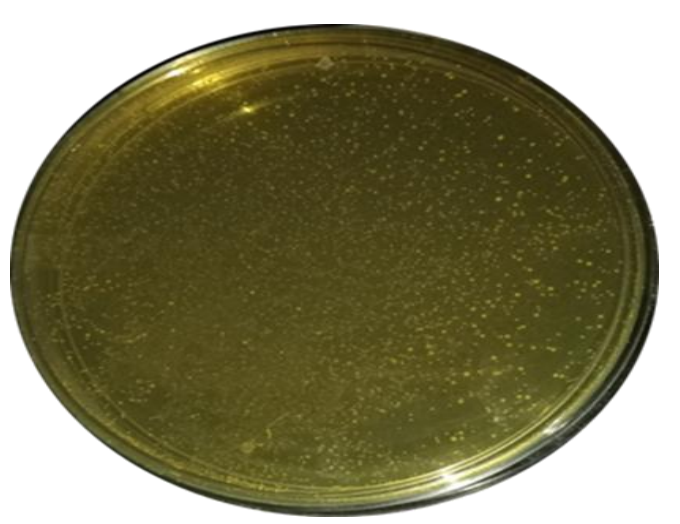


Table.1 Microscopical, Cultural and biochemical Characteristics of LAB

\begin{tabular}{|c|c|c|c|c|c|c|c|c|c|c|c|c|c|}
\hline S.no. & Isolate no. & $\begin{array}{l}\text { Gram's } \\
\text { staining }\end{array}$ & Morphology & Catalase & Motility & $\begin{array}{c}2 \% \\
\mathrm{NaCl}\end{array}$ & $\begin{array}{l}4.5 \% \\
\mathrm{NaCl}\end{array}$ & $\begin{array}{l}6.5 \% \\
\mathrm{NaCl}\end{array}$ & $\begin{array}{l}10 \\
{ }^{\circ} \mathrm{C}\end{array}$ & $\begin{array}{c}40^{\circ} \\
\mathrm{C}\end{array}$ & $45^{\circ} \mathrm{C}$ & Creatine & $\begin{array}{l}\text { Identi } \\
\text { fied } \\
\text { ac }\end{array}$ \\
\hline 1 & $\begin{array}{c}\text { DS, } 1-7,9 \text {, } \\
22,24,32, \\
37,42, \\
47-54,56, \\
57,62\end{array}$ & + & Rod & - & - & - & \pm & - & - & + & + & + & $\begin{array}{c}\text { Lacto } \\
\text { bacill } \\
\text { us }\end{array}$ \\
\hline 2 & $\begin{array}{c}\text { DS, } 8,10, \\
11 \\
13-15,18, \\
21,36,58,59 \\
, 61\end{array}$ & + & Cocci & - & - & + & + & - & + & + & \pm & + & $\begin{array}{c}\text { Strept } \\
\text { ococc } \\
\text { us }\end{array}$ \\
\hline 3 & $\begin{array}{c}\text { DS, } 12,16,1 \\
7, \\
20,30,39,55\end{array}$ & + & Cocci & - & - & + & + & \pm & + & + & \pm & + & $\begin{array}{c}\text { Enter } \\
\text { ococc } \\
\text { us }\end{array}$ \\
\hline 4 & $\begin{array}{c}\text { DS, } 19,23 \\
25-29, \\
31,33, \\
34,35,38,40\end{array}$ & + & Cocci & - & - & + & \pm & \pm & + & + & + & + & $\begin{array}{c}\text { Leuco } \\
\text { nosto } \\
c\end{array}$ \\
\hline \multicolumn{14}{|c|}{ DS-Dairy starter culture, + denotes positive reaction, - denotes negative reaction, \pm denotes variable } \\
\hline
\end{tabular}


Int.J.Curr.Microbiol.App.Sci (2020) 9(9): 2499-2506

Table.2 LAB fermentation of Carbohydrate

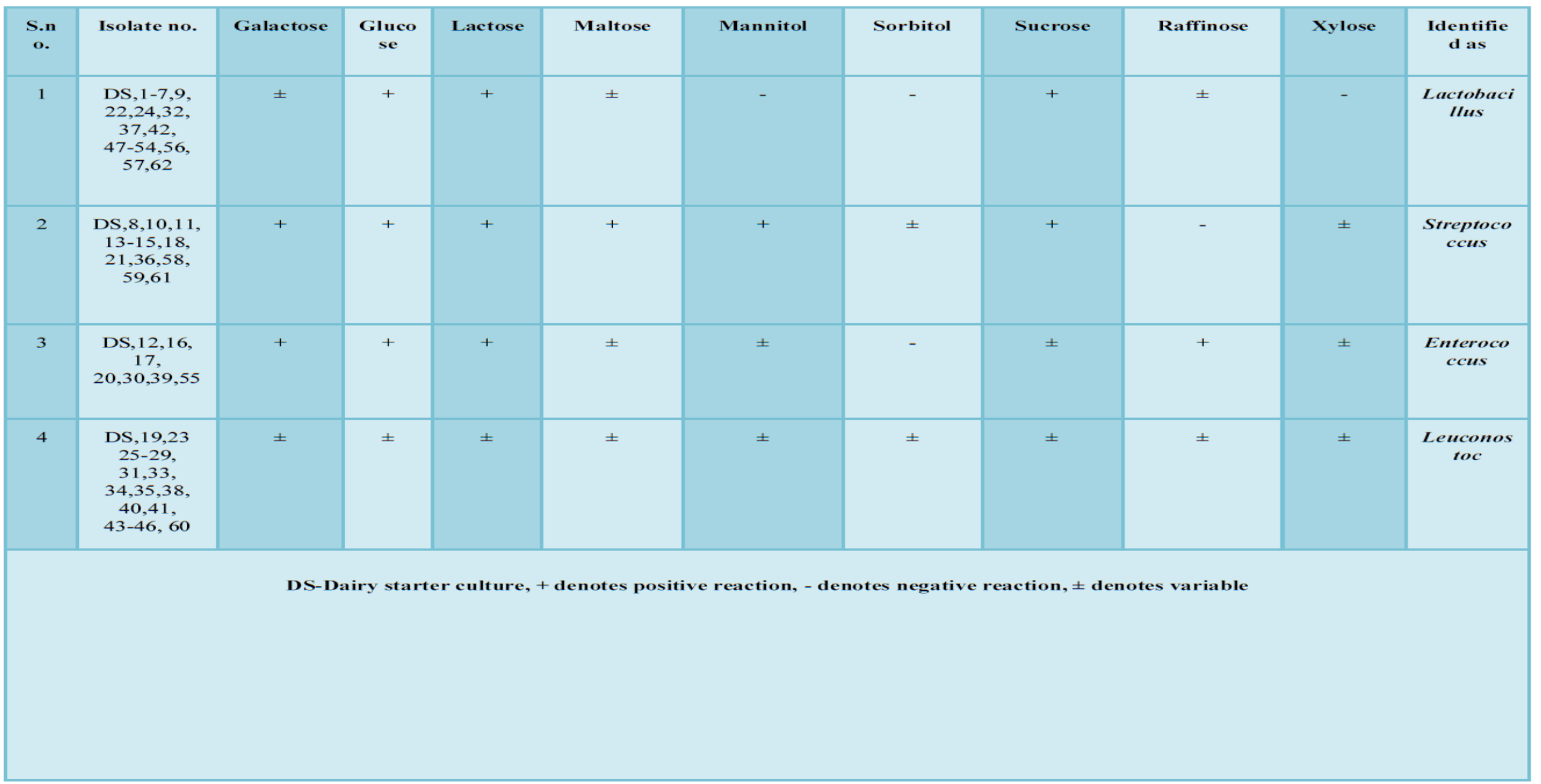


Fig.3 Rod Shaped LAB at 100X magnification

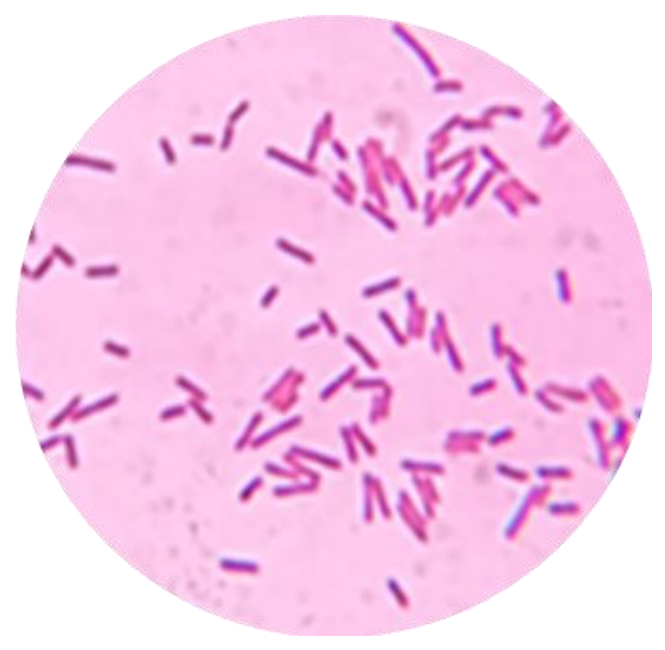

Fig.4 Cocci Shaped LAB at 100X magnification

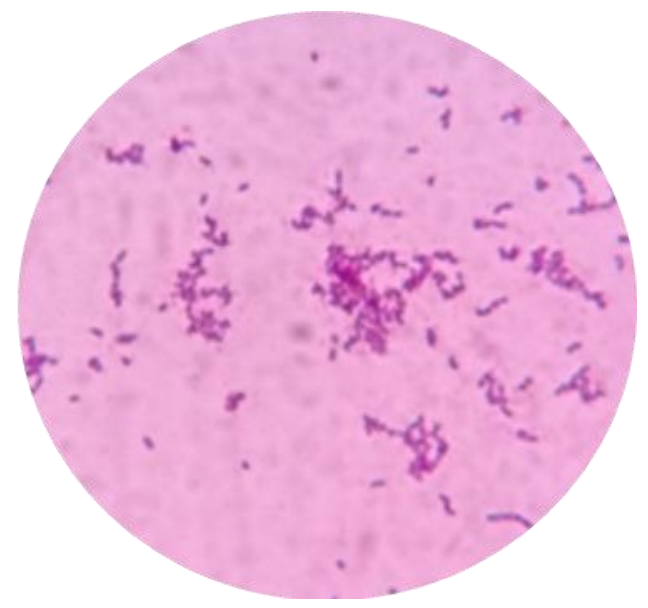

A total of 62 isolates were selected from 150 isolates, among them 38 are Lactococci and 24 are Lactobacilli. The results were in close agreement with Wassie \& Wassie(2016) and Chowdhury \& Islam(2016) who reported that 62isolates shows negative reaction for catalase and motility test. Rod shaped bacteria of Lactobacilli have been able to grow at $4.5 \% \mathrm{NaCl}$ and some of the isolates have not grownat 2 and $6.5 \% \mathrm{NaCl}$. All Lactococci isolates were able to grow at a concentration of $2 \%, 4.5 \%$ and $6.5 \% \mathrm{NaCl}$. All Lactococci isolates were capable of growing at $10^{\circ} \mathrm{C}$, $40^{\circ} \mathrm{C}$ and $45^{\circ} \mathrm{C}$ temperature whereas all Lactobacilli isolates were capable of growing at $40^{\circ} \mathrm{C}$ and $45^{\circ} \mathrm{C}$ and some of the isolates were unable to grow at $10^{\circ} \mathrm{C}$.

The results of the fermentation of carbohydrates are shown in Table 2. Isolates which ferment galactose, glucose, lactose, sorbitol, sucrose, raffinose were identified as Lactobacillus but were not able to ferment sugars like mannitol, sorbitol and xylose. Streptococcus were characterised by the positive fermentation galactose, glucose, lactose, sucrose but failed to ferment raffinose and some of the isolates showed varied reaction with sorbitoland xylose. Enterococcus had varied reaction to ferment 
the sugars like maltose, mannitol, sucrose and xylose but failed to ferment sorbitol. Leuconostoc had the ability to ferment all sugars and varied reaction taken for carbohydrate fermentation test and morphological characters. The results of these studies were comparable with that of the findings of Yadav et al., (1993) with regard to characteristics of Lactobacillus, Streptococcus, Enterococcus and Leuconostoc.

All the sixty two isolates were subjected to starter activity test by Horrel-Elliker method. Isolates No. DS 6, 9, 12, 18 and 39 were found to be highest producers of acid as per the protocol with the mean acid production after 3.5 hours of incubation being $0.261 \pm 0.002, \quad 0.262 \pm 0.002, \quad 0.255 \pm 0.001$, $0.263 \pm 0.001$ and $0.255 \pm 0.001$ of lactic acid respectively. All the 62 isolates were subjected to creatine test. Some of the isolates have developed pink colour within in few minutes that shows large amount of acetyl methyl carbinol and diacetyl present in the culture where as some of the isolates took up to ten minutes to developed pink colour which indicates very small amount of acetyl methyl carbinol and diacetyl present in the culture.

Out of 18 curd samples, a total of 62 LAB isolates were selected from 150 isolates, among them 24 isolates Lactobacillus, 12 isolates Streptococcus, 19 isolates Leuconostoc, 7Enterococcus species were found at genus level. Further research will be done on the molecular characterisation of isolates and their utilisation in fermented dairy products.

\section{Acknowledgement}

The authors would like to acknowledge College of Food and Dairy Technology, for their help and providing laboratory facility.

\section{References}

Abhinav Pathak and Nimisha Dutta, (2016).Isolation and identification of antagonistic Lactobacillus acidiophilus from curd. International Journal of Scientific and Research Publications. 6(6): 2250-3153.

Alrubaye, H. H., Fakhry S. S., andJebur, Z. A. (2018). Lactobacillus spp. Isolated from Dairy Products. JSM Microbiology, 6(1): 1048.

Bai, L. and Ji, S. (2017). Isolation and identification of lactic acid bacteria from koumiss in Eastern Inner Mongolia of China. In AIP Conference Proceedings, 1794(1):p. 050005). AIP Publishing.

Chowdhury, T., and Islam, S. (2016).Isolation, identification and determination of probiotic potential of lactic acid bacteria from local curd. International Journal of Scientific \& Engineering Research, ,7(4), 263-267.

De man, J.C, and Sharpe, M.E. (1960).Journal AppiedBacteriology.,23:130-135

Haghshenas, B., Nami, Y., Almasi, A., Abdullah, N., Radiah, D., Rosli R., and Khosroushahi, A. Y. (2017).Isolation and characterization of probiotics from dairies.Iranian journal of microbiology,9(4): 234.

Heller, K. J., (2016). Probiotic bacteria in dairy foods: product characteristics and starter organisms. American Journal of Clinical Nutrition, 73 (2): 384.

KarasuRamasamy, T., and Suyambulingam, K. (2015).Molecular characterization of lactobacillus sp, from Indian curd and its Antagonistic effects on uropathogens of Diabetic patients.International Research Journal of Biological Sciences, 4(8): 14-22.

Kebede A., (2007). Isolation, Characterization and identification of lactic acid bacteria 
involved in traditional fermentation of borde, an Ethiopian cereal beverage. African Journal of Biotechnology, 6(12), 1469-1478.

Kumar, A., and Kumar, D. (2014). Isolation and characterization of bacteria from dairy samples of Solan in Himachal Pradesh for identification of Lactobacillus spp.International Journal of Pharmaceutical Sciences Review and Research, 25(110):e114.

Mulyawati, A. I., Jatmiko, Y. D., Mustafa I., and Ardyati, T., (2019). Diversity of lactic acid bacteria isolated from fermented mare's milk products based on PCR-RFLP analysis. In IOP Conference Series: Earth and Environmental Science, 230(1).

Ravi, V., Prabhu, M., and Subramanyam, D. (2011).Isolation of bacteriocin producing bacteria from mango pulp and its antimicrobial activity.Journal of Microbiology and Biotechnology Research, 1(2): 54-63.

Vanniyasingam, Kapilan and Vasantharuba, (2019). Isolation and characterization of potential probiotic lactic acid bacteria isolated from cow milk and milk products. AGRIEAST, 13(1): 32-43.

Wassie M., andWassie,T. (2016). Isolation and identification of lactic acid bacteria from raw cow milk.International Journal of Advanced Research and Biological Sciences, 3(8), 44-49.

Yadav, J. S., Grover, S., \&Batish, V. K. (1993). A comprehensive dairy microbiology. Metropolitan Book Co.(P) Ltd.

\section{How to cite this article:}

Krishnaveni, A., B. Murugan, T. R. Pugazhenthi, I. Manikkavasagan and Aravindh Babu, R. P. 2020. Isolation and Identification of LABs through Morphological and Biochemical Characteristics from Curd Sample. Int.J.Curr.Microbiol.App.Sci. 9(09): 2499-2506. doi: https://doi.org/10.20546/ijcmas.2020.909.312 